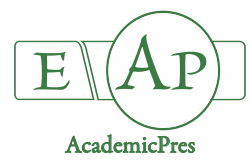

\title{
Vegetative Growth, Flowering and Attributes of Physicochemical Quality in Blackberry 'Tupy' Fruits Grown in Chihuahua, Mexico
}

\author{
Nydia E. MORENO-ROBLES, Juan L.JACOBO-CUELLAR, \\ Ramona PÉREZ-LEAL, MaríaJ. RODRÍGUEZ-ROQUE, \\ Rafael A. PARRA-QUEZADA, Nuvia ORDUÑO-CRUZ, Oscar CRUZ-ALVAREZ*
}

\author{
Autonomous University of Chihuahua, Faculty of Agrotechnological Sciences, Pascual Orozco Avenue, Campus 1, Santo Niño, CP 31350 \\ Chibuahua,Mexico;nydiaedith.nemr@gmail.com; jljacobo@uach.mx; perezleal@hotmail.com; janeth2807@gmail.com; raparra@uach.mx; \\ norduno@hotmail.com; ocruz@uach.mx(*corresponding author)
}

\begin{abstract}
The aim of this research was to evaluate the vegetative growth, flowering and some attributes of physicochemical quality in blackberry 'Tupy' fruits cultivated in Chihuahua, Mexico. The study was carried out in San Juanito and La Finca with twentyfive replications per site. The length and number of sprouts, flowering, total soluble solids (TSS), total titratable acidity (TTA), pH, colour, ascorbic acid (AA), total anthocyanins (TA), total phenols (TP) and antioxidant capacity (AC) were evaluated. San Juanito presented the blackberry plants with the longest sprout length $(169.71 \mathrm{~cm})$, but their number was similar to La Finca, which also showed statistical significance with respect to the minimum temperature range $(-2.9$ and -1.2 ${ }^{\circ} \mathrm{C}$ ), which manifested itself in less accumulation of cold units (658) and degree days (886). The flowering event started at 108 Julian days (April 19) for San Juanito completely evading the occurrence of late frosts, while La Finca maintained a $10 \%$ risk. The fruits harvested in the Finca showed the highest content of TA $\left(75.7 \mathrm{mg}\right.$ cyanid-3-glucosid $\left.100 \mathrm{~g}^{-1}\right)$, maintaining the fruit quality without changes for both sites. The results indicate that the environmental temperature conditions of San Juanito are suitable for vegetative growth and floral development, by completely avoiding the occurrence of late frosts and obtaining fruits with quality similar to that harvested in orchards with commercial production.
\end{abstract}

Keywords: alternative crops; bioactive compounds; cold units; degree days; late frost; Rubus sp.

Abbreviations: AA: Ascorbic acid; AC: antioxidant capacity; CI: Confidence intervals; CU: Cold units; DD: Degree days; TA: total anthocyanin; TO: Thermal oscillation; TP: total phenols; TSS: total soluble solids; TTA; total titratable acidity; WS: Weibull-Sweden

\section{Introduction}

The $56 \%$ of the territorial surface in Mexico is considered arid and with low water availability, and the northern zone (Baja California, Sonora, Chihuahua, Coahuila, Nuevo Leon and Tamaulipas) occupies the largest proportion of the territory with these conditions (Ramirez et al., 2011), with an interannual variation of precipitation between 200 and $800 \mathrm{~mm}$ and with evaporation levels of 2,000 mm (Ramirez-Legarreta et al., 2008). The state of Chihuahua is one of the main apples 'Golden Delicious' and 'Red Delicious' [Malus sylvestris (L.) Mill. var. domestica (Borkh) Mansf.] producers with $89.2 \%$ of the total value of national production (SIAP, 2018).
However, for the production of one ton of apple, $492 \mathrm{~m}^{3}$ of water is required (Rios et al., 2017), and if it is considered that the prevailing climatic conditions of the region are of a dry warm summer with an average annual temperature of $18{ }^{\circ} \mathrm{C}$, with oscillations between -12 and $25{ }^{\circ} \mathrm{C}$ and precipitation of $500 \mathrm{~mm}$ with less than $5 \%$ of winter rain (Parra-Quezada et al., 2008), the fruit growers are in the urgent need to resort to the use and overexploitation of aquifers (Cera-Campos et al., 2019), since for 2015 the level of extraction was $311.28 \mathrm{Mm}^{3}$ year, while the recharge is estimated to be less than $37 \%$, generating a water deficit that threatens the future agricultural production (Rios et al., 2017), where there is also the frequent problem of the occurrence of late frosts (Ramirez et al., 2011). 
In view of the situation described above, several alternative crops have been evaluated which, in addition to having lower water and cold winter requirements (Strik and Thompson, 2009; Segantini et al., 2015; Cera-Campos et al., 2019), allow the producer maintain and/or acquire an adequate economic income for their families (ParraQuezada et al., 2008; El Yaacoubi et al., 2016), with the consequent generation of jobs and economic benefits as part of the implementation of the systems of production (Clark and Finn, 2014; Frias-Moreno et al., 2019). Among these alternatives are the blackberry (Rubus sp.), a fruit species native to Europe, Asia and North America, which is described as a plant with shrub growth and bright black fruit with sweet and aromatic flavour (Croge et al., 2016), whose increase in cultivation is associated with high demand and profitability of the fruit, rapid return at investment and intensive use of hand labour (Hussain et al., 2017). Among the varieties of blackberry that exist, 'Tupy' (hybrid between the variety of blackberry 'Comanche' and Boysenberry,) is the most widely used in Mexico and Brazil for its high yield, fruit quality, vigorous growth and excellent postharvest behaviour (Hussain et al., 2016).

The geographic area of the western state of Chihuahua, presents a series of competitive and comparative advantages with respect to the states of Michoacán, Jalisco and Colima that are the traditional producers of blackberry in Mexico, and may even be a potential competition for Baja California, which during the period of 2012-2018 the area planted increased to 722 ha (SIAP, 2018), where the main export market is the United States of America, Canada, the United Kingdom and the Netherlands. Therefore, the aim of this study was to evaluate the vegetative growth, flowering and some attributes of physicochemical quality in blackberry 'Tupy' fruits cultivated in Chihuahua, Mexico.

\section{Materials and Methods}

\section{Experiment location and plant material}

The evaluation was conducted during the months of April-June 2017, at sites San Juanito (28 $18^{\prime} 19^{\prime \prime} \mathrm{N}$ and $106^{\circ} 32^{\prime} 26^{\prime \prime} \mathrm{W}$ ) with 1,701 meters above sea level (masl), a precipitation and average annual temperature of $350 \mathrm{~mm}$ and $22^{\circ} \mathrm{C}$, respectively. Likewise, La Finca $\left(28^{\circ} 06^{\prime} 53.6^{\prime \prime} \mathrm{N}\right.$ and $\left.107^{\circ} 03^{\prime} 20.7^{\prime \prime} \mathrm{W}\right)$ at altitude $2,197 \mathrm{~m}$, with a precipitation and average annual temperature of $496 \mathrm{~mm}$ and $18{ }^{\circ} \mathrm{C}$, respectively. The plant material consisted of the blackberry 'Tupy', acquired in February 2016 in Michoacán, Mexico. The prevailing physicochemical characteristics of the soil in San Juanito were: clay-sandy texture, $1.95 \%$ organic matter content, $\mathrm{pH} 7.1$, electrical conductivity

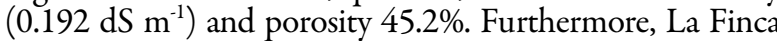
presented silty clay texture, $2.58 \%$ organic matter, $\mathrm{pH}(6.6)$, electrical conductivity and porosity of $0.171 \mathrm{dS} \mathrm{m}^{-1}$ and $37.2 \%$, respectively.

\section{Crop management}

The transplant was performed bare root with a distance of $1 \mathrm{~m}$ between plants and on boards with dimensions of 60 $\times 0.90 \times 0.25 \mathrm{~m}$ (length $\mathrm{x}$ width $\mathrm{x}$ height) and $3 \mathrm{~m}$ separation between them. The driving system used was a
"V" espalier. The water supply was made by a drip irrigation system, where they were applied 2 to 3 irrigations per week and the volume of water applied was 0.6-3.0 litres per plant, depending at the environmental temperature, relative humidity and stages phenological of the crop. Fertilization was done according to the recommended by Perez and Vazquez (2003) of 100-80-80 NPK formula, which nitrogen is fractionated to transplantation, vegetative growth and after harvest; for the case of phosphorus and potassium, it was carried out at the beginning of the rainy season (June 2016). The control of weeds was carried out manually at the rows and with a dewatering machine between them.

Maximum and minimum temperatures, probability of frost and accumulation of degree days

The probability of occurrence of late frosts was calculated (Ortiz, 1987) for a temperature of $-2{ }^{\circ} \mathrm{C}$ with information of daily minimum temperatures, validated and purified from the years 2000-2017, obtained for the Campbell Scientific agro climatic station automated with data logger CR10X, equipped with various sensors for the registration of climatic variables and located $190 \mathrm{~m}$ away from the experimental site.

From March 1 and until the flowering stage (June 6) ended, with the use of maximum and minimum temperatures of 2017 per study site, degree days (DD) (critical temperatures of 4.5 and $35^{\circ} \mathrm{C}$ ) were estimated using the "University of California Agriculture and Natural Resources" platform (https ://www. ipm. ucanr. edu/Weather/index.html).

\section{Selection of plants by site and experimental unit}

Between sites and within them, plants were selected based at their height and health (visual absence of attack by pests and diseases). The experimental unit consisted of a plant with twenty-five replications per site. With respect to fruit quality, different sample sizes were used; for the evaluation of TSS, TTA, pH and colour, the experimental unit consisted of $10 \mathrm{~g}$ of fruit, whereas for the determination of AA they were $4 \mathrm{~g}$ and for TP, TA and AC, $5 \mathrm{~g}$ were used. All the evaluations had four replications.

\section{Variables evaluated}

\section{Length and number of sprouts}

By site and in each one of the selected plants, the number of sprouts was counted and with the help of conventional metric tape (flexometer) its length $(\mathrm{cm})$ was determined. The data was collected every eight days during the April-June 2017 period.

Flowering

The number of floral sprouts of the selected plants was recorded by site and date of evaluation. The number of floral sprouts accumulated over time during the flowering event.

Total soluble solids (TSS), total titratable acidity (TTA) and $p H$

The parameters of TSS, TTA and $\mathrm{pH}$ were determined by macerating $10 \mathrm{~g}$ of fruit per site to obtain juice. The TSS 
982

were quantified with a SMART-1 $1^{\circ}$ portable automatic digital refractometer (ATAGO, USA). To evaluate the percentage of citric acid (TTA), $5 \mathrm{~mL}$ of juice were taken and neutralized with $0.1 \mathrm{~N} \mathrm{NaOH}$, using $1 \%$ phenolphthalein as indicator. The $\mathrm{pH}$ was determined with a benchtop potentiometer HI $5521^{\circ}$ series (HANNA Instruments, USA) with a $\mathrm{pH}$ range of 0-14 and an accuracy of \pm 0.01 .

\section{Colour}

Its evaluation was performed at the epidermis of the fruit in the equatorial region with a portable colorimeter tristimulus CR-300 series (Konica Minolta, USA), registering the initial values $L^{*}, a^{*}$ and $b^{*}$. Subsequently, the chromaticity parameters $=\left(a^{2}+b^{2}\right)^{1 / 2}$ and tonality $=$ hue $=\arctan \left(b^{*} a^{-1}\right)$ were calculated.

\section{Ascorbic acid $(A A)$}

It was estimated according to the method proposed by Jagota and Dani (1982) with slight modifications. $4 \mathrm{~g}$ of fruit were homogenized in $5 \mathrm{~mL}$ of $20 \%$ trichloroacetic acid; the mixture was allowed to stand for $5 \mathrm{~min}$ in cold (ice) and centrifuged for $20 \mathrm{~min}$ at $15,000 \mathrm{rpm}$ at $4{ }^{\circ} \mathrm{C}$. Subsequently, an aliquot of $0.2 \mathrm{~mL}$ of the supernatant of each sample was taken and $1.8 \mathrm{~mL}$ of distilled water and 0.2 $\mathrm{mL}$ of the $10 \%$ Folin-Ciocalteu reactive were added. The mixture was stirred vigorously and left to stand for $10 \mathrm{~min}$ to subsequently perform the absorbance reading at $760 \mathrm{~nm}$. The concentration was expressed in $\mathrm{mg} 100 \mathrm{~g}^{-1}$ fresh weight (fw), by calibration of a standard curve of ascorbic acid.

\section{Extract preparation}

A portion of $5 \mathrm{~g}$ of fresh blackberry was vigorously mixed with $10 \mathrm{~mL}$ of acidified methanol $(0.1 \% \mathrm{HCl})$ at room temperature. Afterwards, the extracts were filtered and stored at $-20{ }^{\circ} \mathrm{C}$ until analysis. The extracts were made in four replications and they were used to determine the antioxidant compounds of blackberry (total phenolic compounds, total anthocyanin content, and total antioxidant capacity).

Totalphenolic (TP)

Total phenolic content was performed following the methodology indicated by Rodríguez-Roque et al. (2013). $0.2 \mathrm{~mL}$ of extract was mixed with $0.2 \mathrm{~mL}$ of Folin-Ciocalteu reagent and $2 \mathrm{~mL}$ of $20 \% \mathrm{Na}_{2} \mathrm{CO}_{3}$. The sample was made up at $10 \mathrm{~mL}$ with distilled water and maintained in darkness during an hour at room temperature. The absorbance at $725 \mathrm{~nm}$ was measured (spectrophotometer Lambda 25, PerkinElmer). Results were expressed as mg of gallic acid per $100 \mathrm{mg}$ of sample (fw).

\section{Total anthocyanin (TA)}

Total anthocyanins were determinate according to the $\mathrm{pH}$ differential method reported by Wrolstad (1976), slightly modified. $5 \mathrm{~mL}$ of blackberry extract were diluted with $10 \mathrm{~mL}$ of buffer solution $(0.025 M$ potassium chloride $\mathrm{pH}=1.0$ or $0.4 M$ sodium acetate $\mathrm{pH}=4.5)$. The extracts were maintained in darkness during 30 minutes at room temperature. After that, the absorbance at 520 and $700 \mathrm{~nm}$ was measured (spectrophotometer Lambda 25, PerkinElmer). Total anthocyanin concentration was calculated in basis of the following equations:

$\mathrm{A}=\left(\mathrm{A}_{510 \mathrm{~nm}}-\mathrm{A}_{700 \mathrm{~nm}}\right) \mathrm{pH} 1.0-\left(\mathrm{A}_{510 \mathrm{~nm}}-\mathrm{A}_{700 \mathrm{~nm}}\right) \mathrm{pH} 4.5$

and

TA (mg of cyanidin-3-glucoside $\left.100 \mathrm{~g}^{-1} \mathrm{fw}\right)=$

$=\left(\frac{\mathrm{A} \times \mathrm{MW} \times \mathrm{DF} \times 1000}{\varepsilon \times \mathrm{L}}\right) \times 21$

where $\mathrm{A}$ is the absorbance of extracts at different wavelength and $\mathrm{pH}, \mathrm{MW}$ corresponded to the molecular weight of cyanidin-3-glucoside (449.2 $\left.\mathrm{g} \mathrm{mol}^{-1}\right)$, DF is the dilution factor, $\mathcal{E}$ is the molar absorptivity coefficient from cyanidin-3-glucoside (26900) y L, is the cuvette optical path length $(1 \mathrm{~cm})$.

\section{Antioxidant capacity $(A C)$}

The AC was carried out according to the methodology reported by Brand-Williams et al. (1995), with some modifications. A portion of $0.2 \mathrm{~mL}$ of extract was mixed with $3.8 \mathrm{~mL}$ of a methanolic DPPH (2,2-diphenyl-1picrylhydrazyl at $\left.0.025 \mathrm{~g} \mathrm{~L}^{-1}\right)$. Samples were maintained in darkness during $30 \mathrm{~min}$. The decrease in the DPPH radical absorbance at $515 \mathrm{~nm}$ was measured (spectrophotometer Lambda 25, PerkinElmer). Results were expressed as \% of $\mathrm{DPPH}$ inhibition as described in the following equation:

$$
\% \text { DPPH inhibition }=\left(\frac{\mathrm{A}_{0}-\mathrm{A}_{1}}{\mathrm{~A}_{0}}\right) \times 100
$$

where $A_{0}$ is the initial absorbance (methanolic DPPH solution), $A_{1}$ is the absorbance of the sample.

\section{Statistical analysis}

The number and length of sprouts were subjected to the non-parametric Mann-Whitney test $(\mathrm{p} \leq 0.05)$ (Sprent and Smetson, 2001). The phenological event of flowering was modelled with Weibull-Sweden modified by Pennypacker et al. (1980). The Weibull-Sweden model can be expressed as follows in its integrated version (Ramirez-Legarreta et al., 2008):

\section{$y=1-\mathrm{e}^{\left[-\left(\frac{t}{b}\right)^{c}\right]}$}

where: $y=$ proportion of flowering per site, $b=$ estimator of the flowering rate in its inverse form $(1 / b), c=$ function parameter of the shape of the curve and lacks units and $\mathrm{t}=$ time measured in days and degree days with critical temperatures of 4 and $35^{\circ} \mathrm{C}$ (Anstey, 1965). The contrast of the event of flowering between sites was made based on the beginning, term, requirement of thermal units during the flowering event and rate of increase in time (thermal units). The fruit quality data were subjected to the Student's " $t$ " test $(p \leq 0.05)$ for two populations. In all the procedures, the statistical analysis program SAS 9.1.3 was used.

\section{Results}

Vegetative growth (length and number of sprouts)

The growth of the sprouts showed statistical differences $(\mathrm{p} \leq 0.05)$ for San Juanito $(169.71 \mathrm{~cm})$, which exceeded by 20.33\% La Finca with $135.27 \mathrm{~cm}$ (Table 1), however, the number of sprouts was similar between both sites. 
Table 1. Vegetative growth in blackberry 'Tupy' in two sites in western Chihuahua, Mexico

\begin{tabular}{ccc}
\hline Site & Sprouts length $(\mathrm{cm})$ & Number of sprouts \\
\hline San Juanito & $169.71 \mathrm{a}$ & $1.76 \mathrm{a}$ \\
La Finca & $135.27 \mathrm{~b}$ & $1.68 \mathrm{a}$ \\
\hline
\end{tabular}

Note: Means with the same letter within columns are equal according to the non-parametric Mann-Whitney $(\mathrm{p} \leq 0.05)$

\section{Flowering}

The analysis of climate data available at sites near stations assessment allowed to generate confidence intervals for minimum and maximum temperatures, which shows that the average minimum temperatures showed differences $(\mathrm{p} \leq 0.05)$ in La Finca with values between -2.9 and $-1.2{ }^{\circ} \mathrm{C}$, while San Juanito, the interval for the minimum average temperature fluctuated between 0.15 and $1.8^{\circ} \mathrm{C}$. In the case of maximum mean temperatures, the confidence intervals were statistically equal (Table 2). On the other hand, the flowering event analysed from the perspective of the DD accumulation (with critical temperatures of 4 and $35^{\circ} \mathrm{C}$ ) (Fig. 1) and with the modified Weibull-Sweden model (Table 3), it can be observed that the value of the slopes of each curve (site) show statistical difference (Fig. 2).

Table 2. Confidence intervals for the mean of minimum and maximum temperatures evaluated in blackberry 'Tupy' in two sites in western Chihuahua, Mexico

\begin{tabular}{|c|c|c|c|c|c|c|}
\hline \multirow{2}{*}{ Site } & \multicolumn{2}{|c|}{ CI for temperature $\mathbb{Q}\left({ }^{\circ} \mathrm{C}\right)$} & \multicolumn{3}{|c|}{$\mathrm{TO}\left({ }^{\circ} \mathrm{C}\right)$} & \multirow{2}{*}{$\mathrm{DD}$} \\
\hline & Min & Max & $\mathrm{CU}$ & Min & Max & \\
\hline San Juanito & $0.15 \leq \bigotimes \geq 1.8 \mathrm{~b}$ & $16.0 \leq \bigotimes \geq 17.6 \mathrm{a}$ & 754 & $\begin{array}{c}-2.1-18.9 \\
(40.5)\end{array}$ & $\begin{array}{c}6.1-32.6 \\
(17.7)\end{array}$ & 1029 \\
\hline La Finca & $-2.9 \leq \mathbb{\nabla} \geq-1.2 \mathrm{a}$ & $16.4 \leq \bigotimes \geq 18.0 \mathrm{a}$ & 658 & $\begin{array}{c}-4.1-14.9 \\
(63.5)\end{array}$ & $\begin{array}{c}3.9-31.1 \\
(15.5)\end{array}$ & 886 \\
\hline
\end{tabular}

Note: Means with the same letter inside CI columns ( $\min$ and $\max$ ) are equal according to the non-parametric Mann-Whitney test (p $\leq 0.05)$. CU: Cold units; TO: Thermal oscillation; in parentheses the coefficient of variation per site (\%) is indicated; DD: Degree days estimated during the period from March 1 to June 6

Table 3. Indicators of the modified model of Weibull-Sweden (W-S) for the flowering stage in blackberry 'Tupy' cultivated in two sites in western Chihuahua, Mexico

\begin{tabular}{ccccc}
\hline \multirow{2}{*}{ Site } & W-S model & \multicolumn{2}{c}{ Indicators of model adjustment } & DD between 5 and 95\% \\
\cline { 2 - 4 } & $\mathrm{Y}=1-\mathrm{e}^{[-(\mathrm{t} / \mathrm{b}) \mathrm{c}]}$ & Value grade $(1 / \mathrm{b})$ & $\mathrm{R}^{2}(\%)$ & $\mathrm{CV}(\%)$ \\
\hline San Juanito & $\mathrm{Y}=1-\mathrm{e}^{[-(\mathrm{t} / 585.94) 7.26)]}$ & $17.06 \mathrm{E}-04 \mathrm{a}$ & 99.9 & 0.6 \\
La Finca & $\mathrm{Y}=1-\mathrm{e}^{[-(\mathrm{t} / 733.06) 5.86]}$ & $13.64 \mathrm{E}-04 \mathrm{~b}$ & 99.7 & 390 \\
\hline
\end{tabular}

Note: The percentage of flowering is obtained by substituting in the equation the value of $\mathrm{t}$ in degree days with beginning of calculation on March 1 at the time of the flowering event. $\mathrm{R}^{2}$ : Correlation coefficient. CV: Coefficient of variation. Means with the same letter in the grade column (1/b) signify statistical equality between them with $95 \%$ certainty

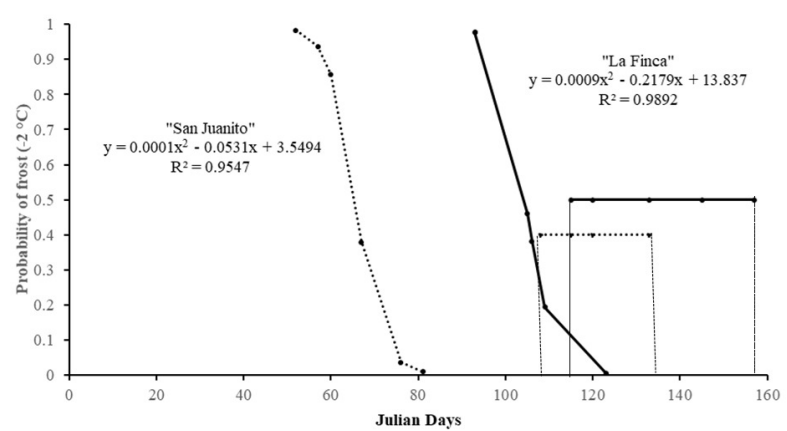

Fig. 1. Probability of occurrence of frost $\left(-2^{\circ} \mathrm{C}\right)$ and flowering event of blackberry 'Tupy' cultivated in two sites in western Chihuahua, Mexico

\section{Physicochemical quality of the fruit}

The data analysis showed statistical equality $(\mathrm{p} \leq 0.05)$ in the parameters of TSS, TTA, $\mathrm{pH}, \mathrm{AA}$, colour, TP and AC between the evaluation sites. However, the fruits harvested in San Juanito showed significant variation with respect to the content of TA with $75.7 \mathrm{mg}$ cyanid-3-glucosid $100 \mathrm{~g}^{-1}$ (Table 4).

\section{Discussion}

With respect to the length of canes, the values found in

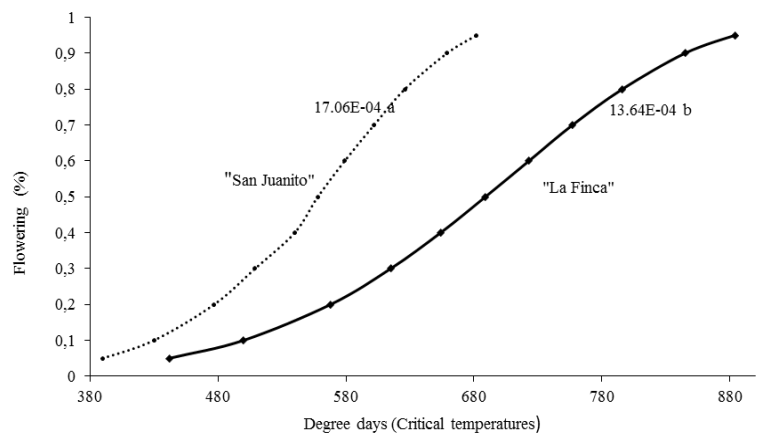

Fig. 2. Flowering (\%) in blackberry 'Tupy' cultivated in two sites in western Chihuahua, Mexico based at degree days accumulation. Strokes with the same letter mean statistical equality in slope values

San Juanito were lower than those reported by Eyduran $e t$ al. (2010), who when working with the American varieties of blackberry 'Ness', 'Cherokee', 'Arapaho', 'Chester Thornless', 'Navaho', 'Black Satin', 'Dirksen Thornless' and 'Jumbo', reported an average value of $226.93 \mathrm{~cm}$ in the length of canes. These differences could be attributed to the genotype and environment (genotype $x$ environment), since being plants with one year of establishment, it could be considered that they still require time to increase photo assimilated reserves in their roots (Croge et al., 2018), and with it, having a longer length and number of sprouts for 
Table 4. Parameters of physicochemical quality of blackberry 'Tupy' fruit grown in two sites in western Chihuahua, Mexico

\begin{tabular}{ccc}
\hline Parameter & Site \\
\cline { 2 - 3 } & San Juanito & La Finca \\
\hline Total soluble solids ( ${ }^{\circ}$ Brix $)$ & $11.00 \mathrm{a}$ & $9.90 \mathrm{a}$ \\
\hline Total titratable acidity $($ citric acid $\%)$ & $2.30 \mathrm{a}$ & $2.01 \mathrm{a}$ \\
$\mathrm{pH}$ & $3.13 \mathrm{a}$ & $3.19 \mathrm{a}$ \\
Brilliance $\left(\mathrm{L}^{*}\right)$ & $23.74 \mathrm{a}$ & $21.89 \mathrm{a}$ \\
Chromaticity $\left(\mathrm{C}^{*}\right)$ & $2.41 \mathrm{a}$ & $2.24 \mathrm{a}$ \\
Hue $\left({ }^{\circ}\right.$ hue $)$ & $16.78 \mathrm{a}$ & $18.78 \mathrm{a}$ \\
Ascorbic acid $\left(\mathrm{mg} 100 \mathrm{~g}^{-1}\right)$ & $17.10 \mathrm{a}$ & $17.01 \mathrm{a}$ \\
Total phenols $\left(\right.$ mg gallic acid $\left.100 \mathrm{~g}^{-1}\right)$ & $225.78 \mathrm{a}$ & $193.33 \mathrm{a}$ \\
TA (mg cyanid-3-glucosid $\left.100 \mathrm{~g}^{-1}\right)$ & $43.84 \mathrm{~b}$ & $75.70 \mathrm{a}$ \\
\hline Antioxidant capacity $(\%$ DPPH inhibition) & $72.99 \mathrm{a}$ & $70.50 \mathrm{a}$ \\
\hline
\end{tabular}

Note: TA: Total anthocyanins. Values with the same letter within rows are statistically equal according to the Student's " $\mathrm{t}$ " test ( $\mathrm{p} \leq 0.05)$

the next growth cycle. On the other hand, Strik and Thompson (2009) indicated that the number of sprouts in blackberry may be associated with the age of the plant, nutritional status and variety, although a greater number of sprouts does not always imply higher yield, as reported by Takeda et al. (2003), in 'Chester Thornless'. However, in raspberry (Rubus idaeus) 'Autumn Bliss' Alvarado-Raya et al. (2016) report that with 30 and $40 \mathrm{~m}^{-2}$ canes they presented a greater number of fruits in relation to densities of 10 and 20 canes $\mathrm{m}^{-2}$.

The flowering event showed a lag between the evaluation sites, since the plants grown in San Juanito began the sprouting of floral sprouts at 108 Julian days (April 19), completely avoiding the probability of occurrence of frosts with a difference of eight days (April 26), compared to La Finca, the latter site still with $10 \%$ risk of damage to flowers due to late frosts. In practical terms, this can be viewed with a difference of 202 DD between the two sites to complete $95 \%$ of the flowering stage, where San Juanito required 682 DD and flowering stage occurred more quickly and consistently, as well, if one takes into account the presence of lower thermal oscillation with respect to minimum temperatures, favours greater cold accumulation, it could also be considered an earlier harvest and with the possible advantage of being able to obtain better prices in the market. It is known that 'Tupy' is a variety with cold requirements of 215 hours below $7.2^{\circ} \mathrm{C}$ (Takeda et al., 2003, Muratalla et al., 2013), due to this it has been able to adapt to tropical and subtropical conditions from Mexico and Brazil (Perez and Vasquez, 2003; Hussain et al., 2016; Croge et al., 2016) through the use of growth regulators and pruning (Clark and Finn, 2014; Segantini et al., 2015). On the other hand, Lopez-Medina and Moore (1999) indicate that exposure to cold does not necessarily cause an increase in the number of knots, however, the induction and subsequent floral differentiation is presented in an accelerated manner. Similarly, Parra-Quezada et al. (2008) when evaluating the flowering in raspberry 'Autumn Bliss' in Guerrero, Chihuahua, Mexico, point out that the sprouting period started at 191 days (July 11) so they completely evade the problem of late frosts, but not, the damages caused by hailstorms and torrential rains. On the other hand, Warmund and Krumme (2008) indicate that cold requirements in blackberry are between 200 and $600 \mathrm{~h}<7.2$ ${ }^{\circ} \mathrm{C}$, however, these requirements may vary between varieties
(Muratalla et al., 2013), because it also indicates the influence of hormonal balance, photoperiod and solar radiation (El Yaacoubi et al., 2016).

Similar concentrations of TSS and citric acid (TTA) are reported by Hussain et al. (2017) for blackberry 'Tupy' $\left(10.9 \pm 0.3{ }^{\circ}\right.$ Brix and $3.20 \pm 0.03 \%$ citric acid $)$ and 'Xavante' $\left(10.8 \pm 0.2^{\circ}\right.$ Brix and $3.20 \pm 0.02 \%$ citric acid $)$, cultivated in two growth cycles under conditions subtropical in Brazil, where in addition these authors, as in this study, indicate not having found significance with respect to $\mathrm{pH}$, the latter, according to Clark and Flinn (2014) allows the fruits to gather the appropriate characteristics to be consumed in fresh and processed. In contrast, Perez and Vazquez (2003) when evaluating the quality of the fruits of the varieties 'Brazos', 'Comanche' and 'Cherokee' cultivated in Santiago Ixcuintla, Nayarit, Mexico, report data of 8.5 and $8.7^{\circ}$ Brix for 'Cherokee' and 'Brazos' however, 'Comanche' showed a value of $10.5^{\circ}$ Brix similar to the one observed in San Juanito, behaviour that can be associated to the effect of the genotype when 'Comanche' is a parent in the generation of the variety 'Tupy' (Hussain et al., 2016), as well as the soil texture, organic matter, electrical conductivity and environmental temperature prevailing in the site, during the growth and development of the fruit (Croge et al., 2016).

The background colour of the fruit plays an important role as an index of quality and as a criterion of visual selection for the final consumer. Hussain et al. (2017) indicate 'Tupy' values lower than those found in this study in ${ }^{*} \mathrm{~L}=18.1 \pm 0.4$ and hue $(13.1 \pm 0.4)$, however, for the purity of colour, they indicate a data of $2.7 \pm 0.2$. The findings of this study suggest that the colour development of the epidermis of the fruit was not affected by the maximum and minimum temperature conditions prevailing during its mooring, growth and maturation, as indicated by Croge $e t$ al. (2016) when evaluating the performance of several cultivars of blackberry ('Guarani', 'Xavante' and 'Cherokee') including 'Tupy', grown in Cerro Azul, Parana, Brazil.

One of the reasons that explains the increase in the consumption of blackberry, blueberry (Vaccinium sp.) and raspberry (Rubus spp.) is related to its potential to inhibit and reduce the harmful effect caused by oxidative stress (Dudonne et al., 2009; Frias-Moreno et al., 2019), generated during respiration and cellular aging (Chaves et al., 2018). Among the most important antioxidant 
compounds water-soluble, is ascorbic acid (vitamin C), whose concentrations found were similar to those reported by Pantelidis et al. (2007) in the varieties 'Choctaw', 'Thornless Evergreen', 'Chester Thornless' and 'Hull Thornless' with values of $14.6 \pm 1.2,17.5 \pm 2.7,14.3 \pm 0.9$ and $14.5 \pm 1.3 \mathrm{mg} 100 \mathrm{~g}^{-1}$, respectively. Likewise, Fu et al. (2015) when evaluating the concentration of ascorbic acid in small, medium and large fruits of raspberry (Rubus hirsutus Thunb.) native to China found values of $16.33 \pm$ $0.02,23.28 \pm 0.29$ and $16.35 \pm 0.50 \mathrm{mg} / 100 \mathrm{~g}$, respectively.

Perhaps one of the secondary metabolites by which the blackberry fruit is characterized is associated with its high concentration of anthocyanins and their conjugates (cyanidin-O-glucoside, cyanidin-O-rutinoside, cyanidin-Omalonylhexoside and cyanidin-O-galactoside) (Chaves et al., 2018). In this sense, results similar to those found in San Juanito are indicated by Hussain et al. (2017) in 'Tupy' and 'Xavante' of $36.2 \pm 31$ and $34.4 \pm 2.8 \mathrm{mg} 100 \mathrm{~g}^{-1}$, respectively. In contrast, Pantelidis et al. (2007) report values between $125.6 \pm 1.6$ and $152.2 \pm 8.4 \mathrm{mg}$ cyanid-3glucosid $100 \mathrm{~g}^{-1}$ for 'Choctaw', 'Thornless Evergreen', 'Chester Thornless' and 'Hull Thornless' that surpass that found in La Finca. Similarly, in previous studies conducted in the area of Cuauhtemoc, Chihuahua, Mexico, contrasting values are reported for similar fruits such as blueberry (Vaccinium corybosum L.) (105 and $250.4 \mathrm{mg}$ cyanid-3-glucosid $100 \mathrm{~g}^{-1}$ ) and raspberry (Rubus sp.) 'Heritage' (15.0 and $34.0 \mathrm{mg}$ cyanid-3-glucoside/100 $\mathrm{g}^{-1}$ ) (Cera-Campos et al., 2019; Frias-Moreno et al., 2019). In this sense it is important to point out that the variation found between the sites can be associated with the variation in the edaphoclimatic conditions, as indicated by Hussain $e t$ al. (2017), without leaving aside, considerations related to the state of maturity and nutritional of the fruit, method of extraction and analysis of the sample (Rodriguez-Roque $e t$ al., 2013), as well as the molar extinction coefficient ( $\varepsilon$ ) used for the calculation of the concentration (Chaves et al., 2018), that in this work $\varepsilon=26,900$ was used.

In spite of not having found significant variation with relation of TP, lower values are reported by Hussain $e t$ al.

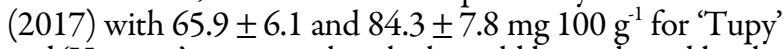
and 'Xavante', respectively, which could be explained by the conditions of crop management. However, they are not comparable to the 170.3 and $250.4 \mathrm{mg}$ gallic acid $100 \mathrm{~g}^{-1}$ reported by Cera-Campos et al. (2019) in blueberry 'Blueray' and 'Bluejay' grown in the same area of this study. Frias-Moreno et al. (2019) when evaluating the quality of fruit in raspberry 'Heritage' cultivated in conventional and organic management system, they report values between 196.6 and $343.9 \mathrm{mg}$ gallic acid $100 \mathrm{~g}^{-1}$, where the highest concentration of total phenols was obtained with the system of organic management.

Worldwide, the increase in the production and consumption of blueberry, raspberry and blackberry is associated with changes in eating habits and search of horticultural products that allow health care (Frias-Moreno et al., 2019), whose properties range from antioxidants and anticancer agents (Muratalla et al., 2013), and in this study, the data found surpass what was indicated for juniper fruit (Juniperus communis) $(1.92 \pm 1.81 \% \mathrm{DPPH}$ inhibition)
(Dudonne et al., 2009) but were lower than indicated for wild raspberry (Rubus hirsutus Thunb) (80.33\% DPPH inhibition) (Fu et al., 2015). Variations that according to Rodriguez-Roque et al. (2013) and Cera-Campos et al. (2019) is a consequence of the composition and joint concentration of its antioxidant components, such as vitamins, phenols and anthocyanins, this could explain why, although the concentration of total anthocyanins present in the fruits was different, it was not significantly reflected in the behaviour of the AC.

\section{Conclusions}

Based at the results obtained among the sites evaluated, there is sufficient evidence to indicate that San Juanito showed the best temperature conditions for the growth and development of the blackberry 'Tupy' plant, which manifested itself with greater length of sprouts and lower probability of occurrence of late frosts. On the other hand, with the exception of the content of total anthocyanins, the physicochemical quality was similar.

\section{Acknowledgements}

The authors express their gratitude to the company " $\mathrm{La}$ norteñita S.A. de C.V.", Regional Agricultural Union of Fruit Growers of the State of Chihuahua (UNIFRUT) and to PRODEP-UACH-PTC-330, for the technical and financial support granted for the completion of the present research.

\section{Conflict of Interest}

The authors declare that there are no conflicts of interest related to this article.

\section{References}

Alvarado-Raya H, Avitia-Garća E, Castillo-González AM (2016). Production of 'Autumn Bliss' raspberry with different cane densities in the Valley of Mexico. Revista Mexicana de Ciencias Agrícolas 7(1):1729.

Anstey TH (1965). Prediction of full bloom date for apple, pear, cherry, peach and apricot from air temperature data Journal of the American Society for Horticultural Science 88:57-66.

Brand-Williams W, Cuvelier ME, Berset C (1995). Use of a free radical method to evaluate antioxidant activity. LWT - Food Science and Technology 28(1):25-30.

Cera-Campos JI, Jacobo-Cuellar JL, Rodríguez-Roque MJ, Parra-Quezada RA, Soto-Caballero MC, Pérez-Leal R, Cruz-Alvarez O (2019). Vegetative growth and quality of blueberry fruit cultivated in Chihuahua, Mexico. Notulae Botanicae Horti Agrobotanici ClujNapoca 47(2):450-457.

Chaves VC, Boff L, Vizzotto M, Calvete E, Reginatto FH, Simões CM (2018). Berries grown in Brazil: anthocyanin profiles and biological properties. Journal of the Science of Food and Agriculture 98(11):43314338. 
986

ClarkJR, Finn CE (2014). Blackberry cultivation in world. Revista Brasileira deFruticultura36(1):46-57.

Croge CP, Cuquel FL, Biasi LA, Bona CM (2016). Performance of blackberry cultivars in Cerro Azul - PR Revista Brasileira de Fruticultura 38(3):e-141.

Dudonne S, Vitrac X, Coutiere P, Woillez M, Merillon JM (2009). Comparative study of antioxidant properties and total phenolic content of 30 plant extracts of industrial interest using DPPH, ABTS, FRAP, SOD, and ORAC assays. Journal of Agricultural and Food Chemistry, 57(5):1768-1774.

El Yaacoubi A, Malagi G, Oukabli A, Citadin I, Hafidi M, Bonhomme M., Legave JM (2016). Differentiated dynamics of bud dormancy and growth in temperate fruit trees relating to bud phenology adaptation, the case of apple and almond trees. International Journal of Biometeorology 60(11):1695-1710.

Eyduran E, Eyduran SP, Khawar KM, Agaoglu YS (2015). Determination of the best blackberry cultivar using various statistical techniques. African Journal of Agricultural Research 5(9):898-909.

Frias-Moreno MN, Olivas-Orozco GI, González-Aguilar GA, BenitezEnriquez YE, Paredes-Alonso A, Jacobo-Cuellar JL, ... Parra-Quezada RA (2019). Yield, quality and phytochemicals of organic and conventional raspberry cultivated in Chihuahua. Notulae Botanicae Horti Agrobotanici Cluj-Napoca 47(2):522-530.

Fu Y,Zhou X, Chen S, Sun Y, Shen Y, Ye X (2015). Chemical composition and antioxidant activity of Chinese wild raspberry (Rubus hirsutus Thunb.).LWT - Food Science and Technology 60(2):1262-1268.

Hussain I, Roberto SR, Koyama R, de Assis AM, Colombo RC, Fonseca ICB, Antunes LEC (2017). Performance of 'Tupy' and 'Xavante' blackberries under subtropical conditions. Fruits 72(3):166-173.

Hussain I, Roberto SR, Batista FIC, de Assis AM, Koyama R, Antunes LEC (2016). Phenology of 'Tupy' and 'Xavante' blackberries grown in a subtropical area. Scientia Horticulturae 201:78-83.

Jagota SK, Dani HM (1982). A new colorimetric technique for the estimation of vitamin $\mathrm{C}$ using Folin phenol reactive. Analytical Biochemistry 127(1):178-182.

Lopez-Medina J, Moore JN (1999). Chilling enhances cane elongation and flowering in primocane-fruiting blackberries. HortScience 34(4):638640.

Muratalla LA, Jaen-Contreras D, Arévalo-Galarza L (2013). La producción de frambuesa y zarzamora en México [The production of raspberry and blackberry in Mexico]. Agroproductividad 6(5):1-9.

Ortiz SCA (1987). Elementos de agrometeorología cuantitativa: con aplicaciones en la república mexicana [Elements of quantitative agrometeorology: with applications in the Mexican Republic]. Universidad Autónoma Chapingo: Departamento de Suelos. Texcoco, Mexico.

Pantelidis G, Vasilakakis M, Manganaris G, Diamantidis G (2007). Antioxidant capacity, phenol, anthocyanin and ascorbic acid contents in raspberries, blackberries, red currants, gooseberries and Cornelian cherries. Food Chemistry 102(3):777-783.
Parra-Quezada RA, Ramírez-Legarreta MR, Jacobo-Cuellar JL, ArreolaAvila G (2008). Fenología de la frambuesa roja 'Autumn Bliss' en Guerrero, Chihuahua, México ['Autumn Bliss' red raspberry phenology at Guerrero, Chihuahua State, Mexico]. Revista Chapingo Serie Horticultura 14(1):91-96.

Pennypacker SP, Knoble HD, Antle CE, Madden LV (1980). A flexible model for studying plant disease progression. Phytopathology 70(3):232-235.

Pérez BMH, Vázquez VV (2003). Comportamiento de la zarzamora en el clima cálido [Performance of blackberry in a warm climate]. Revista ChapingoSerie Horticultura 9(2):305-314.

Ramírez-Legarreta MR, Jacobo-Cuéllar JL, Gardea-Béjar AA, ParraQuezada RA (2008). Model on floral development of apple [Malus sylvestris(L.) Mill. var. domestica (Borkh) Mansf.] Red and Golden Delicious as a decision-making tool for integrated disease management. Revista Mexicana de Fitopatología 26(2):153-163.

Ramírez LMR, Ruiz CJA, Medina GG, Jacobo CJL, Parra QRA, Ávila MMR, Amado AJP (2011). Perspectives on the apple production system in Chihuahua facing climate change. Revista Mexicana de Ciencias Agrícolas 2(2):265-279.

Rios FJL, Torres MM, Ruíz EMJA (2017). Productividad del agua en manzano producido bajo diferentes niveles de tecnificación en Cuauhtémoc, Chihuahua, México [Water productivity in apple tree produced under different levels of tecnification in Cuauhtemoc, Chihuahua, Mexico]. Asuntos Económicos y Administrativos 32:135146.

Rodríguez-Roque MJ, Rojas-GraüMA, Elez-Martínez P, Martín-Belloso O (2013). Changes in vitamin C, phenolic, and carotenoid profiles throughout in vitro gastrointestinal digestion of a blended fruit juice. Journal of Agricultural and Food Chemistry 61(8):1859-1867.

Segantini D, Leonel S, Da Silva RAK, Tecchio M, De Souza M (2015). Breaking dormancy of "Tupy" blackberry in subtropical conditions. American Journal of Plant Sciences 6(11):1760-1767.

SIAP (2018). Servicio de Información Agroalimentaria y Pesquera. Atlas agroalimentario 2018 [Agricultural and Livestock Information System. Agroalimentary Atlas 2018]. Retrieved 2019 March 23 from https://nube.siap.gob.mx/gobmx_publicaciones_siap/pag/2018/AtlasAgroalimentario-2018.

Sprent P, Smeeton NC (2001). Applied nonparametric statistical methods. Chapman \&Hall/CRC (3er Ed), Florida, USA.

Strik BC, Thompson E (2009). Primocane-fruiting blackberries: potential for extending harvest season and production regions. HortScience $44(1): 23-24$.

Takeda F, Hummell AK, Peterson DL (2003). Effects of cane number on yield components in 'Chester Thornless' blackberry on the rotatable cross-arm trellis. HortScience 38(3):377-380.

Warmund MR, Krumme J (2008). A chilling model to estimate rest completion of erect blackberries. HortScience 40(5):1259-1262.

Wrolstad RE (1976). Color and pigment analyses in fruit products. Corvallis, OR: Oregon State University. Oregon, USA. 